\title{
Chitosan and Starch Based Intelligent Films with Anthocyanins from Eggplant to Monitor pH Variations ${ }^{\#}$
}

\author{
Seren Bilgiç̧,a, Ece Söğüt ${ }^{1, b, *}$, Atıf Can Seydim ${ }^{1, c}$ \\ ${ }^{I}$ Department of Food Engineering, Suleyman Demirel University, Isparta, Turkey.
} *Corresponding author

\begin{tabular}{|c|c|}
\hline A R T I C L E I N F O & A B S T R A C T \\
\hline $\begin{array}{l}\text { Keywords: } \\
\text { Anthocyanin } \\
\text { Chitosan } \\
\text { Eggplant } \\
\text { pH indicator intelligent packaging } \\
\text { Starch }\end{array}$ & 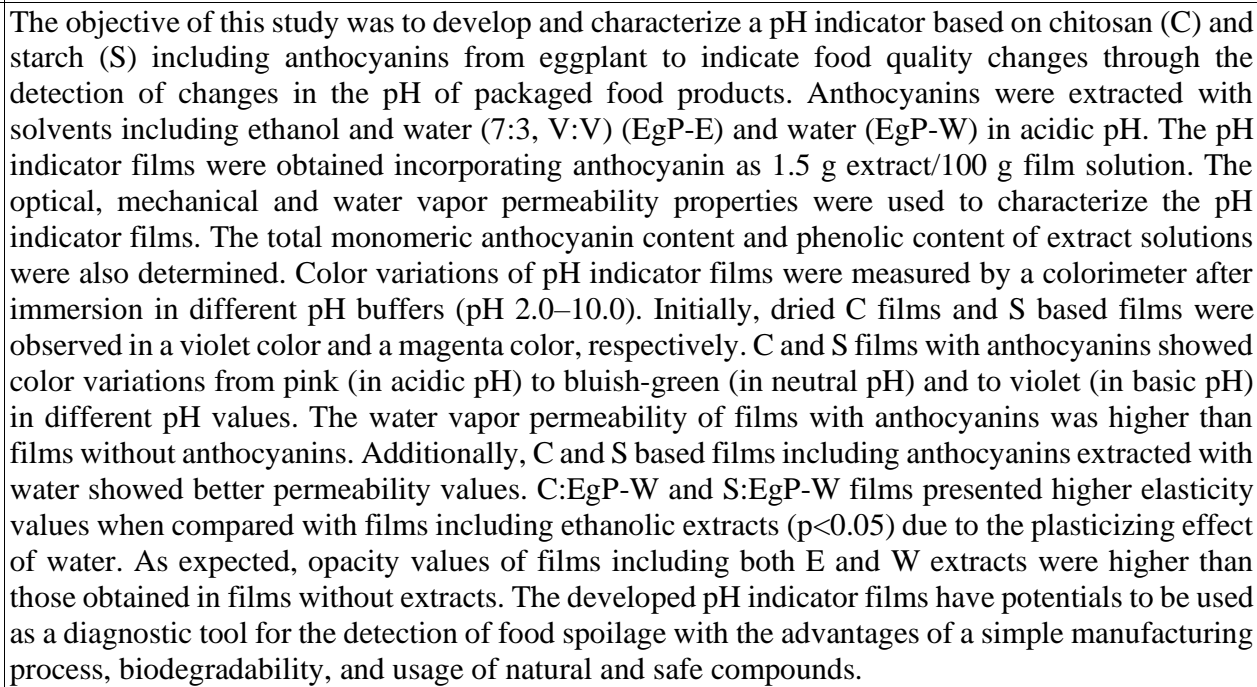 \\
\hline
\end{tabular}

bilgicseren@gmail.com c@atifseydim@sdu.edu.tr

\section{Introduction}

Bio-based polymers are considered as environmentally friendly because they are more easily decomposed in nature than commonly used plastics. Therefore, there is an increasing interest in the development of packaging materials including natural polymers due to their biodegradability and barrier ability against to the transport of moisture, gas, aroma, and lipids (Dutta et al., 2009; Yoshida et al., 2010). In addition, the properties of those bio-based polymers can be changed by the addition of substances such as colorants, antimicrobials, plasticizers, etc. It is quite a new issue that packaging materials obtained from natural polymers are converted into intelligent packaging systems by the addition of different components (Yoshida et al., 2014).

Intelligent packaging is a system providing information on shelf-life, safety and quality of food product by monitoring the changes inside the package (Yam et al., 2005). Among the intelligent packaging systems, colorbased $\mathrm{pH}$ indicators have promising potential use as indicators of oxidation, microbial growth or microbial metabolites (Smolander, 2003; Kerry et al, 2006). Many factors, such as water activity, $\mathrm{pH}$ and oxygen can affect the shelf life of the product. The $\mathrm{pH}$ levels of food products may vary depending on factors such as flavor, consistency and the formation of chemical reactions that may affect shelf life. The food spoilage is usually accompanied by a $\mathrm{pH}$ change, thus the relationship between the food product quality and the changes in $\mathrm{pH}$ is very strong (Veiga-Santos et al., 2011). The correlation between the packaged food product and the changes in $\mathrm{pH}$ during the storage is of great importance. Thus, a smart system that allows the consumer to evaluate the quality of food products with changes in the color of packaging material stemmed from $\mathrm{pH}$ is of the innovative approaches. There is a growing interest on biobased $\mathrm{pH}$ indicator systems such as cassava starch (VeigaSantos et al., 2011), chitosan (Kato et al., 2011; Maciel et al., 2012; Maciel et al., 2015), cornstarch (Silva-Pereira et al., 2015), gum/cellulose matrix (Ma et al., 2017). 
Anthocyanins are polyphenolic plant pigments, which show different colors depending on many factors such as $\mathrm{pH}$, storage temperature, chemical structure, concentration, light, oxygen, solvents and the presence of enzymes, proteins and metallic ions (Castañeda-Ovando et al., 2009).

There are few studies related to $\mathrm{pH}$ indicators based on, chitosan and starch film including anthocyanins, which undergo color modification when exposed to different $\mathrm{pH}$ environments. Thus, in this study, a bio-based intelligent packaging material film with eggplant extracts, as sources of $\mathrm{pH}$ indicators (anthocyanin), incorporated into starch and chitosan matrices were developed. The mechanical properties, water vapor barrier, optical properties of the films were evaluated as well as the color change at different $\mathrm{pH}$ values.

\section{Materials and Methods}

\section{Materials}

Chitosan (C) (ChitoClear ${ }^{\circledR}$ CG1600, high molecular weight $>320 \mathrm{kDa}, 1600 \mathrm{Cps}$ solution at $2 \%$ with acetic acid, $>75 \%$ deacetylated) was purchased from Primex (ChitoClear®, Siglufjordur, Iceland) and starch (S) was supplied from Sigma-Aldrich (St. Louis, Missouri, USA). All chemicals were analytical grade and purchased from Sigma-Aldrich (St. Louis, Missouri, USA). Eggplants were provided from a local market in Isparta/Turkey and stored under suitable conditions prior to extraction.

\section{Extraction of Anthocyanins}

Anthocyanins were extracted from eggplant peels (EgP) according to the method described by Choi et al., (2017) with some modifications. Briefly, $30 \mathrm{~g}$ of EgP was exposed to $100 \mathrm{ml}$ of selected solvent at $\mathrm{pH} 2$ adjusted by an acetic acid solution. Two kinds of solvents were prepared with water $(\mathrm{W})$ and water:ethanol (E) (3:7, v:v). The extraction was performed under room temperature at shaking stirrer during $24 \mathrm{~h}$ followed by ultrasonication for $30 \mathrm{~min}$. All extracts were then filtered under vacuum and concentrated by an evaporator at $40^{\circ} \mathrm{C}$. The concentrated solutions were stored at $-18^{\circ} \mathrm{C}$ prior to their use.

Total Phenolic Content and Anthocyanin Concentration of Extracts

The total anthocyanin content of extracts was determined by the $\mathrm{pH}$-differential method (Giusti and Wrolstad, 2001). Briefly, the pH of the extracted solution $(1 \mathrm{~mL})$ was one adjusted with potassium chloride buffer $(10 \mathrm{~mL}), \mathrm{pH} 1.0$, and the other with sodium acetate buffer $(10 \mathrm{~mL}), \mathrm{pH} 4.5$. After $15 \mathrm{~min}$, the absorbance of each dilution was recorded at the 510 and $700 \mathrm{~nm}$ against a blank cell filled with distilled water. The absorbance of extracts (A) was corrected as follows:

$$
\mathrm{A}=(\mathrm{A} 510-\mathrm{A} 700)_{\mathrm{pH} 1.0}-(\mathrm{A} 510-\mathrm{A} 700)_{\mathrm{pH}} 4.5
$$

The monomeric anthocyanin concentration in the original sample was calculated using the following formula:

$$
\text { Monomeric anthocyanin }=(\mathrm{A} \times \mathrm{MW} \times \mathrm{DF} \times 1000) /(\varepsilon \times 1)
$$

Where MW is the molecular weight $(449.2 \mathrm{~g} / \mathrm{mol}$ for cyanidin-3-glucoside), DF is the dilution factor, and $\varepsilon$ is the molar absorptivity (26,900 for cyanidin-3-glucoside).
Total phenolic content of extracts was determined by the Folin-Ciocalteu colorimetric method (Singleton et al., 1999). The suitable dilutions of all extracts were mixed with Folin-Ciocalteu reagent (Sigma-Aldrich, Missouri, USA) $(0.2 \mathrm{~N})$ and sodium carbonate $(7.5 \% \mathrm{w} / \mathrm{v})$, and measured by reading the absorbance of samples at a wavelength of $765 \mathrm{~nm}$ using a UV-Visible spectrophotometer (Shimadzu, UV-1601, Tokyo, Japan). The results were expressed as $\mathrm{mg}$ gallic acid equivalent per $\mathrm{kg}$ sample.

\section{Film Preparation}

Chitosan (C) at $1 \% \mathrm{w} / \mathrm{w}$ was dissolved in $1 \% \mathrm{w} / \mathrm{w}$ aqueous acetic acid solution. A C film solution was obtained by adding glycerol at $0.20 \%$ w/w (SanchezGonzalez et al., 2010). The starch (S) powder was dissolved in distilled water $(2 \%, \mathrm{w} / \mathrm{w})$ and heated at $80^{\circ} \mathrm{C}$ for $15 \mathrm{~min}$. Then, the film-forming solution was further stirred for $25 \mathrm{~min}$. Glycerol was added to the fully dissolved solutions at $0.40 \% \mathrm{w} / \mathrm{w}$. Both water (W) and water:ethanol (3:7, v:v) (E) based EgP extracts at 5\% v/v in a film solution, were then added to the film solutions and homogenized (DAIHAN HG-15A, Korea) for $5 \mathrm{~min}$. After degassing to avoid the formation of air bubbles, $50 \mathrm{~g}$ of the solution was cast onto a Teflon ${ }^{\circledR}$ coated plate $(\varnothing=150 \mathrm{~mm})$ and dried in ambient conditions for $48 \mathrm{~h}$. All film samples were conditioned at $25^{\circ} \mathrm{C}$ and $50 \% \mathrm{RH}$ for one week before analysis.

\section{Mechanical Properties of Film Samples}

Elastic modulus (EM), tensile strength (TS) and elongation $(\mathrm{E}, \%)$ at break point values were determined by the ASTM standard method D882 (ASTM, 2018). Films $(2.5 \mathrm{~cm} \times 5 \mathrm{~cm})$ were mounted in the film-extension grips of the testing machine (Lloyd LR5, AMETEK, Inc, West Sussex, UK) and stretched at $50 \mathrm{~mm} / \mathrm{min}$ until they broke.

Water vapor permeability and optical properties of film samples

The water vapor permeability (WVP) of film samples were determined according to E96-95 gravimetric method (ASTM, 2016). All film samples were exposed to $100 \% \mathrm{RH}$, and the permeability measurements were performed by weighing the cups periodically (every $1.5 \mathrm{~h}$ for $48 \mathrm{~h}$ ) at $25^{\circ} \mathrm{C}$.

Transparency $(\mathrm{T}, \%$ ) of the films was determined by measuring the percent transmittance at $450 \mathrm{~nm}$ using a UV-vis spectrophotometer (Shimadzu, UV-1601, Tokyo, Japan). Rectangular strips of film samples $(1 \times 4 \mathrm{~cm})$ were obtained to determine the opacity. All films were placed in a UV-vis spectrophotometer test cell, and the absorption spectrum of the sample was obtained from 400 to $800 \mathrm{~nm}$ (Shimadzu, UV-1601, Tokyo, Japan). Film opacity was measured as the area under the curve divided by the film thickness and expressed as absorbance unit (AU nm/mm).

Color Response of Film Samples at Different $p H$ Values

The color changes of the films at different $\mathrm{pH}$ values (2-10) were measured with a Minolta Chroma Meter (CR400, Konica Minolta, Inc., Japan) by immersing the film samples in different $\mathrm{pH}$ buffers. A white standard calibration plate $(\mathrm{Y}=92.7, \mathrm{x}=0.3160, \mathrm{y}=0.3321$ ) was used as a background for the color measurement of the films. All 
measurements were taken at three random locations and results were expressed as CIE $L^{*}, a^{*}$ and $b^{*}$. Tests were carried out in triplicate.

\section{Statistical Analysis}

An analysis of variance (ANOVA) and Tukey's multiple comparison tests was used to compare the different treatments at a 95\% confidence level (Minitab 17 software, Minitab Inc., Brandon, UK). Three observations (at least) were performed for each film, and each experiment was replicated three times.

\section{Results and Discussion}

Total Anthocyanin and Phenolic Content of Egp Extracts

Total monomeric anthocyanin content and phenolic concentration are shown in Table 1 . The total monomeric anthocyanin content ranged from 8.7 to $49.7 \mathrm{mg}$ per $100 \mathrm{~g}$, which is similar to the results obtained by BoulekbacheMakhlouf et al. (2013). The ethanolic extracts showed higher monomeric anthocyanin content, probably due to better extraction in ethanol when used acetic acid solution.

The total phenolic content values obtained for ethanolic extracts were significantly higher than those obtained for the water extracts were. Similar results were presented by Jung et al. (2011), who evaluated the phenolic content of different parts (calyx, leaf, peel, pulp, and stem) of eggplant after extracted with $70 \%$ ethanol and water. In contrast, the anthocyanin content of eggplant extracts obtained in this study was different from reported by Azuma et al. (2008), which might be due to the differences in the growth condition, variety, and cultivation.

\section{Film Characterization}

Mechanical properties of film samples: The EM, TS, and E (\%) values of film samples are shown in Table 2.
$\mathrm{C}:$ EgP-E films exhibited the highest EM and TS values while $\mathrm{S}$ films exhibited the lowest values $(\mathrm{P}<0.05)$. The addition of both extract type into film samples enhanced the mechanical properties of films suggesting that there was an intermolecular crosslink within the matrices of the films (Coughlan et al., 2004). Similarly, Yong et al. (2019) reported that chitosan films including eggplant extracts had higher TS values when compared to neat chitosan films. The enhancement in EM and TS might be probably due to the hydrogen bonding between polymer and phenols in the extracts (Koosha and Hamedi, 2019). C-based films showed significantly higher EM, TS and E values $(\mathrm{P}<0.05)$, which could be explained by the stronger interaction between hydroxyl/amino groups of $\mathrm{C}$ and polyphenols (Yong et al. 2019).

Film samples including W-extracts showed slightly higher elongation capacities probably due to the plasticizing effect of water $(\mathrm{P}<0.05)$. Besides, film samples including ethanolic extracts presented lower elongation values $(\mathrm{P}<0.05)$. Ethanolic extracts might cause an anti-plasticizing effect leading a decrease in flexibility by limiting the motion of polymer chains (Mushtaq et al. 2018). This observation is in agreement with Gutierrez and Alvarez (2018) who studied cornstarch films including natural and modified nano-clays with or without added blueberry extract.

WVP and optical properties of film samples: WVP and optical properties of film samples are shown in Table 3. Sbased films showed higher thickness values when compared to C-based films. The thickness of films decreased when extracts were added to C-based films, whereas the thickness of S-based films including extracts presented higher values $(\mathrm{P}<0.05)$. The interactions between the anthocyanins and film matrix might affect the thickness of film samples. Similar results were reported for chitosan films including natural extracts (cranberry, blueberry, purple sweet potato) by Lozano-Navarro et al. (2017).

Table 1 The anthocyanin and phenolic content of extracts

\begin{tabular}{l|cc}
\hline \multicolumn{1}{c}{ Extract } & Total phenolic content $(\mathrm{mg} \mathrm{GAE} / \mathrm{kg})$ & Total monomeric anthocyanin content $(\mathrm{mg} / 100 \mathrm{~g})$ \\
\hline EgP-E & $1573.7 \pm 1.4^{\mathrm{a}}$ & $49.7 \pm 1.1^{\mathrm{a}}$ \\
EgP-W & $275.2 \pm 8.5^{\mathrm{b}}$ & $8.7 \pm 0.1^{\mathrm{b}}$ \\
\hline
\end{tabular}

${ }^{\mathrm{a}-\mathrm{b}}$ Means in the same column with different superscripts differ significantly $(\mathrm{p}<0.05)$ according to Tukey test.

Table 2. Mechanical properties of film samples

\begin{tabular}{l|ccc}
\hline Film samples & EM $(\mathrm{MPa})$ & TS $(\mathrm{MPa})$ & E $(\%)$ \\
\hline C & $717.27 \pm 40.66^{\mathrm{a}}$ & $13.57 \pm 3.03^{\mathrm{abc}}$ & $16.78 \pm 1.06^{\mathrm{a}}$ \\
C:EgP-W & $718.34 \pm 86.19^{\mathrm{a}}$ & $19.23 \pm 3.19^{\mathrm{ab}}$ & $16.92 \pm 2.44^{\mathrm{a}}$ \\
C:EgP-E & $774.02 \pm 87.48^{\mathrm{a}}$ & $19.29 \pm 3.74^{\mathrm{a}}$ & $16.38 \pm 2.24^{\mathrm{a}}$ \\
S & $153.14 \pm 19.76^{\mathrm{b}}$ & $2.92 \pm 1.47^{\mathrm{bc}}$ & $2.65 \pm 0.42^{\mathrm{b}}$ \\
S:EgP-W & $185.84 \pm 30.81^{\mathrm{b}}$ & $5.14 \pm 0.88^{\mathrm{bc}}$ & $5.21 \pm 0.48^{\mathrm{b}}$ \\
S:EgP-E & $204.33 \pm 32.54^{\mathrm{b}}$ & $5.35 \pm 0.77^{\mathrm{c}}$ & $1.80 \pm 0.33^{\mathrm{b}}$ \\
\hline
\end{tabular}

${ }^{\mathrm{a}-\mathrm{c}}$ Means in the same column with different superscripts differ significantly $(\mathrm{P}<0.05)$ according to Tukey test

Table 3 WVP and optical properties of film samples

\begin{tabular}{l|ccrc}
\hline Film samples & Thickness $(\mu \mathrm{m})$ & WVP $\left(\mathrm{g}-\mathrm{mm} / \mathrm{kPa}-\mathrm{h}-\mathrm{m}^{2}\right)$ & Opacity $(\mathrm{AU} \mathrm{nm} / \mathrm{mm}) \times 10^{3}$ & T $(\%)$ \\
\hline C & $40.00 \pm 6.24^{\mathrm{bc}}$ & $14.31 \pm 1.56^{\mathrm{b}}$ & $1.75 \pm 0.21^{\mathrm{b}}$ & $58.60 \pm 2.36^{\mathrm{a}}$ \\
C:EgP-W & $39.67 \pm 2.08^{\mathrm{bc}}$ & $11.30 \pm 3.46^{\mathrm{b}}$ & $2.19 \pm 0.58^{\mathrm{a}}$ & $55.15 \pm 1.40^{\mathrm{a}}$ \\
C:EgP-E & $32.33 \pm 0.58^{\mathrm{c}}$ & $10.11 \pm 1.68^{\mathrm{bc}}$ & $3.85 \pm 0.35^{\mathrm{ab}}$ & $50.65 \pm 1.45^{\mathrm{a}}$ \\
S & $47.00 \pm 1.00^{\mathrm{ab}}$ & $15.28 \pm 0.39^{\mathrm{c}}$ & $1.98 \pm 0.05^{\mathrm{b}}$ & $40.90 \pm 2.59^{\mathrm{a}}$ \\
S:EgP-W & $50.67 \pm 3.06^{\mathrm{a}}$ & $11.71 \pm 1.94^{\mathrm{bc}}$ & $2.03 \pm 0.57^{\mathrm{b}}$ & $35.15 \pm 0.39^{\mathrm{a}}$ \\
S:EgP-E & $53.67 \pm 1.15^{\mathrm{a}}$ & $37.92 \pm 1.77^{\mathrm{a}}$ & $2.08 \pm 0.60^{\mathrm{ab}}$ & $37.90 \pm 3.19^{\mathrm{a}}$ \\
\hline
\end{tabular}

${ }^{\mathrm{a}-\mathrm{c}}$ Means in the same column with different superscripts differ significantly $(\mathrm{P}<0.05)$ according to Tukey test 
S:EgP-E films showed the highest WVP values, and $\mathrm{C}$ :EgP-E films had the lowest WVP values $(\mathrm{P}<0.05)$. The presence of $\mathrm{EgP}$ extracts in $\mathrm{C}$-based films caused an increase in barrier ability against water. Kurek et al. (2018) reported similar trends for chitosan films including blackberry and blueberry extracts. However, the incorporation of water extracts of $\mathrm{EgP}$ into $\mathrm{S}$ films decreased the WVP values of the film samples $(\mathrm{P}<0.05)$ while adding ethanolic extracts into $\mathrm{S}$ films resulted in a significant increase in WVP values. The decrease in WVP values can be explained by the intermolecular interactions between polymer and phenolics leading a decreased affinity towards water molecules (Kurek et al. 2018). Similarly, Yoshida et al. (2014) reported that the addition of anthocyanins into chitosan films reduced WVP values due to the more compact and dense structure of anthocyanin added films when compared to chitosan films without extracts. In contrast, the increase in WVP values of S:EgP-E might be probably due to the high anthocyanin contents presented in ethanolic extracts, causing less dense structure in S-based films (Liu et al. 2018).

All film samples presented an average clearance, thus good transparency was not achieved with all formulations. In general, $\mathrm{C}$ and $\mathrm{S}$ film samples including extracts showed lower transmittance and higher opacity values, which can be related to the impenetrable matrix light scattering throughout the film (Tongnuanchan et al., 2013). The lower transmittance and higher opacity values are also related to the UV absorption ability of anthocyanins (Peralta et al. 2019).

The opacity values of film samples including ethanolic extracts were found higher than those obtained for films including water extracts $(\mathrm{P}<0.05)$. This behavior might be due to the higher anthocyanin contents of ethanolic extracts absorbing more light (Peralta et al. 2019). Lower transmittance values were also reported by other researchers who studied chitosan films incorporated with anthocyanin rich extratcs (Ma et al. 2018; Wang et al. 2019). In a similar manner, Slavutsky et al. (2012) found a decrease in transparency by the addition of nano-clay (montmorillonite) dependent on the dispersion method used.

Color Changes of Film Samples at Different Ph Values

The color changes of S:EgP-W film samples ranging from red to green-blue in $\mathrm{pH}$ 2-10 buffers are shown in Figure 1 (other films was not shown here). The incorporation of anthocyanin extracts obtained from EgP helped to develop a bio-based intelligent film (Gutierrez et al., 2017). EgP extracts have the potential to change color at different $\mathrm{pH}$ values due to the structural variations occurring within the anthocyanin molecules (Gutierrez and Alvarez, 2018). Film samples started to have a reddish color when exposed to acidic $\mathrm{pH}$ levels (2-6) and then films became bluish green at higher $\mathrm{pH}$ levels (7-10). Similar results were reported for $\mathrm{pH}$-sensitive film samples including anthocyanin from different plant sources such as purple sweet potato (Choi et al., 2017), blueberry pomace (Luchese et al., 2017), red cabbage (Pereira et al., 2015), black bean (Prietto et al., 2017) and grape skin (Ma and Wang, 2016).

Table 4 also shows the color values of film samples as a function of $\mathrm{pH}$ buffers. At higher $\mathrm{pH}$ levels, film samples tended to be darker related to the lower $L^{*}$ values. Film samples immersed in higher $\mathrm{pH}$ levels than 5-6, showed significantly lower $L^{*}$ values $(\mathrm{P}<0.05)$. Besides, the $a^{*}$ and $b^{*}$ values varied as a function of $\mathrm{pH}$. Higher $a^{*}$ values were observed in lower $\mathrm{pH}$ values $(\mathrm{P}<0.05) . b^{*}$ values tended to decrease up to $\mathrm{pH} 5$, and then started to increase at higher $\mathrm{pH}$ values $(\mathrm{P}<0.05)$. It indicates that more reddish and bluish film samples were related to lower and higher $\mathrm{pH}$ values, respectively.

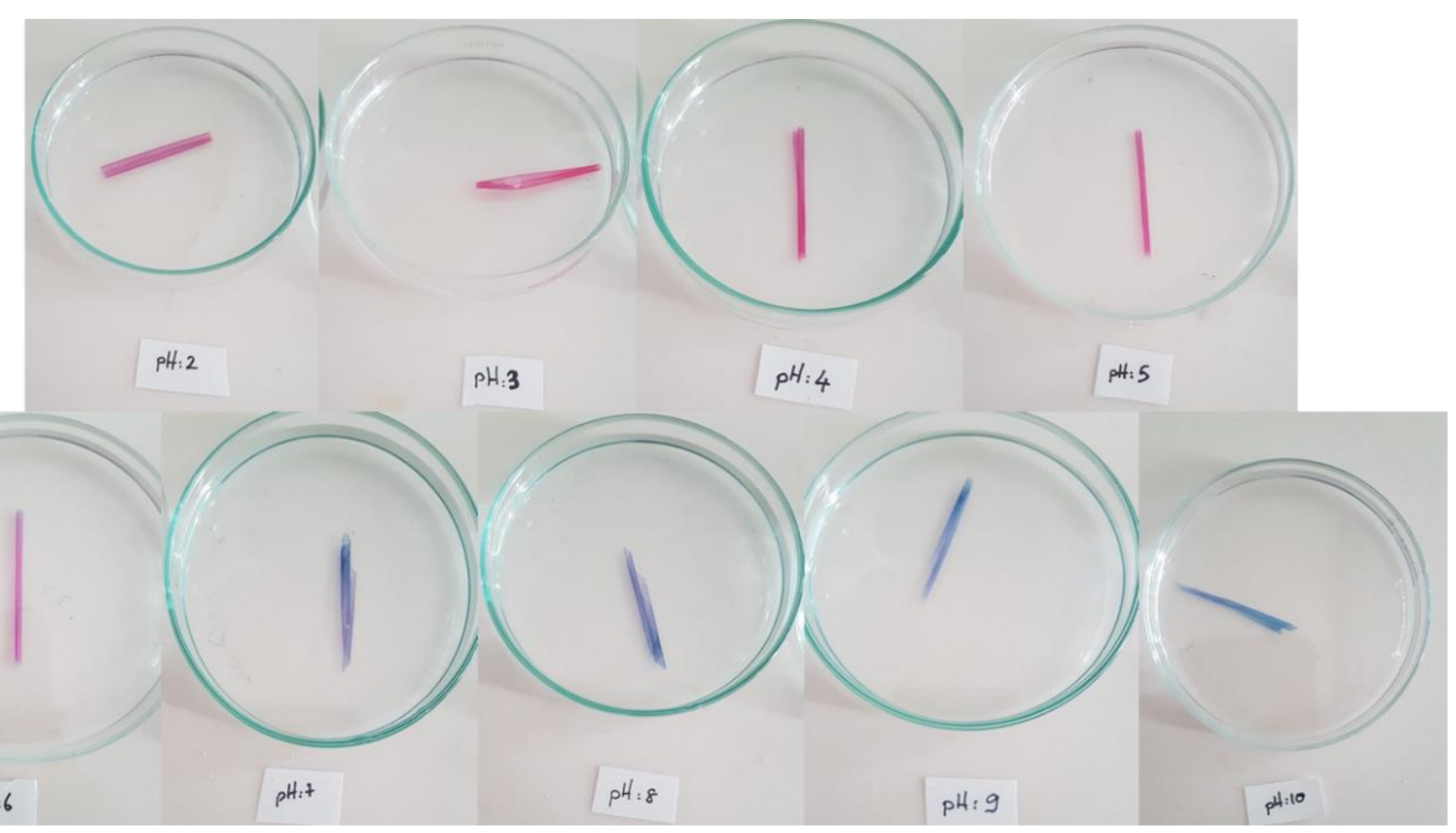

Figure 1 Color response of S:EgP-W film samples in different $\mathrm{pH}$ buffers (other films was not shown here) 
Table $4 L^{*}, a^{*}$ and $b^{*}$ color parameters of film samples immersed in different $\mathrm{pH}$ buffers (2-10).

\begin{tabular}{|c|c|c|c|c|}
\hline \multirow{2}{*}{ Film samples } & \multirow{2}{*}{$\mathrm{pH}$ value } & \multicolumn{3}{|c|}{ Color parameters } \\
\hline & & $L^{*}$ & $a^{*}$ & $b^{*}$ \\
\hline \multirow{9}{*}{$\mathrm{C}: \mathrm{EgP}-\mathrm{W}$} & 2 & $86.99 \pm 0.39^{a}$ & $-0.58 \pm 0.13^{a}$ & $4.36 \pm 0.04^{\mathrm{a}}$ \\
\hline & 3 & $83.60 \pm 0.06^{\mathrm{a}}$ & $-1.56 \pm 0.03^{b}$ & $2.77 \pm 0.01^{\mathrm{bc}}$ \\
\hline & 4 & $86.96 \pm 0.02^{\mathrm{a}}$ & $-2.32 \pm 0.01^{\mathrm{c}}$ & $1.99 \pm 0.01^{\mathrm{de}}$ \\
\hline & 5 & $86.98 \pm 0.28^{a}$ & $-2.49 \pm 0.06^{\mathrm{cd}}$ & $2.21 \pm 0.01^{\mathrm{cd}}$ \\
\hline & 6 & $86.08 \pm 2.23^{\mathrm{a}}$ & $-2.51 \pm 0.22^{\mathrm{cd}}$ & $2.61 \pm 0.52^{b c}$ \\
\hline & 7 & $87.79 \pm 2.12^{\mathrm{a}}$ & $-2.48 \pm 0.11^{\mathrm{cd}}$ & $2.38 \pm 0.25^{\mathrm{bc}}$ \\
\hline & 8 & $86.44 \pm 7.12^{\mathrm{a}}$ & $-1.69 \pm 0.27^{b}$ & $1.42 \pm 0.02^{\mathrm{e}}$ \\
\hline & 9 & $83.92 \pm 0.01^{\mathrm{a}}$ & $-3.23 \pm 0.01^{\mathrm{e}}$ & $3.08 \pm 0.01^{\mathrm{b}}$ \\
\hline & 10 & $85.29 \pm 0.08^{a}$ & $-2.94 \pm 0.04^{\mathrm{de}}$ & $2.91 \pm 0.12^{\mathrm{bc}}$ \\
\hline \multirow{9}{*}{ S:EgP-W } & 2 & $89.35 \pm 0.07^{\mathrm{a}}$ & $-0.18 \pm 0.03^{b}$ & $2.59 \pm 0.60^{\mathrm{bc}}$ \\
\hline & 3 & $88.70 \pm 0.90^{\mathrm{a}}$ & $0.45 \pm 0.08^{a}$ & $2.95 \pm 0.02^{\mathrm{ab}}$ \\
\hline & 4 & $86.01 \pm 0.11^{\mathrm{a}}$ & $-1.26 \pm 0.07^{c}$ & $2.15 \pm 0.01^{\mathrm{c}}$ \\
\hline & 5 & $89.70 \pm 0.03^{\mathrm{a}}$ & $-1.72 \pm 0.05^{\mathrm{d}}$ & $2.47 \pm 0.10^{\mathrm{bc}}$ \\
\hline & 6 & $86.64 \pm 0.64^{\mathrm{a}}$ & $0.50 \pm 0.01^{\mathrm{a}}$ & $2.32 \pm 0.01^{\mathrm{c}}$ \\
\hline & 7 & $83.46 \pm 0.37^{\mathrm{a}}$ & $-1.79 \pm 0.03^{\mathrm{d}}$ & $-1.49 \pm 0.15^{\mathrm{e}}$ \\
\hline & 8 & $82.16 \pm 0.73^{a}$ & $-3.51 \pm 0.06^{\mathrm{f}}$ & $-0.79 \pm 0.31^{\mathrm{d}}$ \\
\hline & 9 & $85.70 \pm 0.18^{a}$ & $-2.38 \pm 0.23^{e}$ & $3.49 \pm 0.09^{\mathrm{a}}$ \\
\hline & 10 & $88.50 \pm 6.80^{\mathrm{a}}$ & $-1.68 \pm 0.16^{\mathrm{d}}$ & $3.18 \pm 0.20^{\mathrm{a}}$ \\
\hline \multirow{9}{*}{ C:EgP-E } & 2 & $88.09 \pm 0.25^{\mathrm{a}}$ & $-1.12 \pm 0.02^{\mathrm{a}}$ & $4.07 \pm 0.03^{\mathrm{a}}$ \\
\hline & 3 & $84.77 \pm 0.08^{\mathrm{bc}}$ & $-1.31 \pm 0.11^{\mathrm{a}}$ & $2.30 \pm 0.24^{\mathrm{ef}}$ \\
\hline & 4 & $83.34 \pm 0.01^{b c}$ & $-2.47 \pm 0.01^{b c}$ & $2.09 \pm 0.02^{\mathrm{f}}$ \\
\hline & 5 & $84.55 \pm 2.18^{\mathrm{bc}}$ & $-2.27 \pm 0.37^{b c}$ & $2.30 \pm 0.01^{\mathrm{ef}}$ \\
\hline & 6 & $85.99 \pm 0.15^{\mathrm{ab}}$ & $-2.02 \pm 0.01^{b}$ & $3.28 \pm 0.01^{\mathrm{b}}$ \\
\hline & 7 & $82.69 \pm 0.02^{c}$ & $-2.37 \pm 0.01^{b c}$ & $2.79 \pm 0.01^{\mathrm{c}}$ \\
\hline & 8 & $83.16 \pm 0.07^{b c}$ & $-2.76 \pm 0.01^{c}$ & $2.72 \pm 0.01^{\mathrm{cd}}$ \\
\hline & 9 & $83.96 \pm 0.08^{b c}$ & $-2.58 \pm 0.04^{\mathrm{c}}$ & $2.41 \pm 0.01^{\mathrm{de}}$ \\
\hline & 10 & $83.68 \pm 0.01^{b c}$ & $-2.73 \pm 0.01^{\mathrm{c}}$ & $2.11 \pm 0.01^{\mathrm{ef}}$ \\
\hline \multirow{9}{*}{ S:EgP-E } & 2 & $85.34 \pm 0.01^{\mathrm{bc}}$ & $0.91 \pm 0.15^{\mathrm{a}}$ & $3.04 \pm 0.13^{\mathrm{c}}$ \\
\hline & 3 & $84.12 \pm 0.49^{\mathrm{d}}$ & $1.03 \pm 0.06^{\mathrm{a}}$ & $5.49 \pm 0.10^{\mathrm{a}}$ \\
\hline & 4 & $82.85 \pm 0.28^{\mathrm{e}}$ & $-2.11 \pm 0.03^{\mathrm{e}}$ & $0.22 \pm 0.05^{\mathrm{g}}$ \\
\hline & 5 & $88.16 \pm 0.01^{\mathrm{a}}$ & $-1.46 \pm 0.01^{\mathrm{cd}}$ & $1.16 \pm 0.00^{\mathrm{f}}$ \\
\hline & 6 & $85.14 \pm 0.11^{\mathrm{cd}}$ & $-2.26 \pm 0.01^{\mathrm{e}}$ & $1.76 \pm 0.01^{\mathrm{d}}$ \\
\hline & 7 & $69.53 \pm 0.13^{\mathrm{g}}$ & $-0.71 \pm 0.11^{b}$ & $-0.52 \pm 0.01^{h}$ \\
\hline & 8 & $85.65 \pm 0.35^{b}$ & $-1.32 \pm 0.04^{\mathrm{cd}}$ & $0.27 \pm 0.06^{\mathrm{g}}$ \\
\hline & 9 & $84.49 \pm 0.35^{\mathrm{cd}}$ & $-1.49 \pm 0.00^{\mathrm{d}}$ & $1.46 \pm 0.04^{\mathrm{e}}$ \\
\hline & 10 & $81.16 \pm 0.16^{f}$ & $-1.21 \pm 0.02^{\mathrm{c}}$ & $4.03 \pm 0.01^{\mathrm{b}}$ \\
\hline
\end{tabular}

${ }^{a-h}$ Means in the same column with different superscripts differ significantly $(\mathrm{P}<0.05)$ according to Tukey test

\section{Conclusion}

Bio-based (chitosan and starch) pH-sensitive intelligent films were successfully obtained. Film samples including extracts showed lower WVP values except for S:EgP-E films and higher EM and TS values when compared to related control films. The transmittance of film samples did not alter significantly for anthocyanin-included films however, the opacity increased with the incorporation of both type of extracts. Both S- and C-based films including anthocyanins showed a color difference as a function of $\mathrm{pH}$, which was reddish in lower $\mathrm{pH}$ and bluish in higher $\mathrm{pH}$ levels. Thus, this study showed the potential of incorporating EgP extracts into $\mathrm{S}$ and $\mathrm{C}$-based matrices in order to develop intelligent bio-based films giving $\mathrm{pH}$ variation information during the storage and handling of a sensitive food product.

\section{References}

ASTM. 2016. Standard test methods for water vapor transmission of materials: E96/E96M-16. In Annual book of American Society for Testing and Materials Standards (Vol. 04.06, pp. 14). West Conshohocken, PA: ASTM.
ASTM. 2018. Standard test method for tensile properties of thin plastic sheeting: D882. In Annual book of American Society for Testing and Materials standards (Vol. 08.01, pp. 12). West Conshohocken, PA: ASTM.

Azuma K, Ohyama A, Ippoushi K, Ichiyanagi T, Takeuchi A, Saito T, Fukuoka H. 2008. Structures and antioxidant activity of anthocyanins in many accessions of eggplant and its related species. J Agric Food Chem., 56:10154-10159.

Boulekbache-Makhlouf L, Medouni, L, Medouni-Adrar S, Arkoub, L, Madani K. 2013. Effect of solvents extraction on phenolic content and antioxidant activity of the byproduct of eggplant. Ind Crops Prod., 49:668-674.

Castaneda-Ovando A, Pacheco-Hernandez MD, Paez-Hernandez ME, Rodriguez JA, Galan-Vidal CA. 2009. Chemical studies of anthocyanins: A review. Food Chem., 113(4):859-871.

Choi I, Lee YJ, Lacroix M, Han J. 2017. Intelligent pH indicator film composed of agar/potato starch and anthocyanin extracts from purple sweet potato. Food Chem., 218:122-128.

Coughlan K, Shaw NB, Kerry JF, Kerry JP. 2004. Combined effects of proteins and polysaccharides on physical properties of whey protein concentrate-based edible films. Journal of Food Science E: Food Engineering and Physical Properties, 69(6):E271-E275. 
Dutta PK, Tripathi S, Mehrotra GK, Dutta J. 2009. Perspectives for chitosan-based antimicrobial films in food applications. Food Chem., 114(4):1173-1182.

Giusti MM, Wrolstad RE. 2001. Characterization and measurement of anthocyanins by UV-visible spectroscopy. Curr Protocol., 1:F1.2.1-F1.2.13.

Gutierrez TJ, Alvarez VA. 2018. Bionanocomposite films developed from cornstarch and natural and modified nanoclays with or without added blueberry extract. Food Hydrocol., 77:407-420.

Gutierrez TJ, Ponce AG, Alvarez VA. 2017. Nano-clays from natural and modified montmorillonite with and without added blueberry extract for active and intelligent food nanopackaging materials. Mater Chem Phys., 194:283-292.

Jung EJ, Bae MS, Jo EK, Jo YH, Lee SC. 2011. Antioxidant activity of different parts of eggplant. J Med Plant Res., 5:4610-4615.

Kato Jr ET, Yoshida CMP, Reis AB, Melo IS, Franco TT. 2011. Fast detection of hydrogen sulphide using a biodegradable colorimetric indicator system. Polym Int., 60:951-956.

Kerry JP, O'Grady MN, Hogan SA. 2006. Past, current and potential utilization of active and intelligent packaging systems for meat and muscle-based products: a review. Meat Sci., 74(1):113-130.

Koosha M, Hamedi S. 2019. Intelligent chitosan/PVA nanocomposite films containing black carrot anthocyanin and bentonite nanoclays with improved mechanical, thermal and antibacterial properties. Prog Org Coat., 127: 338-347.

Kurek M, Garofulić IE, Bakić MT, Ščetar M, Uzelac VD, Galić K. 2018. Development and evaluation of a novel antioxidant and $\mathrm{pH}$ indicator film based on chitosan and food waste sources of antioxidants. Food Hydrocol., 84:238-246.

Liu J, Wang H, Wang P, Guo M, Jiang S, Li X, Jiang S. 2018. Films based on $\kappa$-carrageenan incorporated with curcumin for freshness monitoring. Food Hydrocol. 83:134-142.

Lozano-Navarro JI, Díaz-Zavala NP, Velasco-Santos C, Martínez-Hernández AL, Tijerina-Ramos BI, GarcíaHernández M, Rivera-Armenta JL, Páramo-García U, Reyesde la Torre AI. 2017. Antimicrobial, optical and mechanical properties of chitosan-starch films with natural extracts. Int J Mol Sci., 18(5):997.

Luchese CL, Garrido T, Spada JC, Tessaro IC, de la Caba K. 2017. Development and characterization of cassava starch films incorporated with blueberry pomace. Int $\mathrm{J}$ Biol Macromol., 106:834-839.

Ma Q, Liang T, Cao L, Wang L. 2018. Intelligent poly (vinyl alcohol)-chitosan nanoparticles-mulberry extracts films capable of monitoring $\mathrm{pH}$ variations. Int J Biol Macromol., 108:576-584.

Ma Q, Ren Y, Gu Z, Wang L. 2017. Developing an intelligent film containing Vitis amurensis husk extracts: The effects of $\mathrm{pH}$ value of the film-forming solution. J Clean Prod., 166:85-859.

Ma Q, Wang L. 2016. Preparation of a visual pH-sensing film based on tara gum incorporating cellulose and extracts from grape skins. Sensor Actuat B-Chem., 235:401-407.

Maciel VBV, Yoshida CMP, Franco TT. 2012. Development of a prototype of a colorimetric temperature indicator for monitoring food quality. J Food Eng., 111; 21-27.

Maciel VBV, Yoshida CMP, Franco TT. 2015. Chitosan/pectin polyelectrolyte complex as a $\mathrm{pH}$ indicator. Carbohyd Polym., 132:537-545.
Mushtaq M, Gani A, Gani A, Punoo HA, Masoodi FA.(2018. Use of pomegranate peel extract incorporated zein film with improved properties for prolonged shelf life of fresh Himalayan cheese (Kalari/kradi). Innov Food Sci Emerg., 48:25-32.

Peralta J, Bitencourt-Cervi CM, Maciel VB, Yoshida CM, Carvalho RA. 2019. Aqueous hibiscus extract as a potential natural $\mathrm{pH}$ indicator incorporated in natural polymeric films. Food Packaging and Shelf Life, 19:47-55.

Pereira VA, de Arruda INQ, Stefani R. 2015. Active chitosan/PVA films with anthocyanins from Brassica oleraceae (Red Cabbage) as time-temperature indicators for application in intelligent food packaging. Food Hydrocol., 43:180-188.

Prietto L, Mirapalhete TC, Pinto VZ, Hoffmann JF, Vanier NL, Lim L-T, Dias ARG, Rosa Zavareze E. 2017. pH-sensitive films containing anthocyanins extracted from black bean seed coat and red cabbage. LWT - Food Sci Technol., 80:492-500.

Sánchez-González L, Cháfer M, Chiralt A, González-Martínez C. 2010. Physical properties of edible chitosan films containing bergamot essential oil and their inhibitory action on Penicillium italicum. Carbohyd Polym., 82(2):277-283.

Silva-Pereira MC, Teixeira R, Rawlings JA, Pereira-Junior VA. 2015. Chitosan/ starch blend films with extract from Brassica oleraceae (red cabbage) as a visual indicator of fish deterioration. LWT - Food Sci Technol., 61:258-262.

Singleton, V. L., Orthofer, R., \& Lamuella-Raventos, R. M. (1999). Analysis of total phenols and other oxidation substrates and antioxidants by means of Folin-Ciocalteu reagent. Method Enzymol., 299:152-178.

Slavutsky AM, Bertuzzi MA, Armada M. 2012. Water barrier properties of starch-clay nanocomposite films. Braz J Food Technol., 15:208-218.

Smolander M. 2003. The use of freshness indicators in packaging R. Ahvenainen (Ed.), Novel food packaging techniques, Woodhead Publishing Ltd, Cambridge, pp. 5-21

Tongnuanchan P, Benjakul S, Prodpran T. 2013. Physicochemical properties, morphology and antioxidant activity of film from fish skin gelatin incorporated with root essential oils. J Food Eng., 117(3):350-360.

Veiga-Santos P, Ditchfield C, Tadini CC. 2011. Development and evaluation of a novel $\mathrm{pH}$ indicator biodegradable film based on cassava starch. J Appl Polym Sci., 120:1069-1079.

Wang X, Yong H, Gao L, Li L, Jin M, Liu J. 2019. Preparation and characterization of antioxidant and $\mathrm{pH}$-sensitive films based on chitosan and black soybean seed coat extract. Food Hydrocol., 89:56-66.

Yam KL, Takhistov PT, Miltz J. 2005. Intelligent packaging: Concepts and applications. J Food Sci., 70(1):R1-R10.

Yong et al. (2019) Yong H, Wang X, Bai R, Miao Z, Zhang X, Liu J. 2019. Development of antioxidant and intelligent $\mathrm{pH}$ sensing packaging films by incorporating purple-fleshed sweet potato extract into chitosan matrix. Food Hydrocol., 90:216-224.

Yoshida CMP, Bastos CEN, Franco TT. 2010. Modeling of potassium sorbate diffusion through chitosan films. Food Sci Technol., 43:584-589.

Yoshida CMP, Maciel VBV, Mendonça MED, Franco TT. 2014. Chitosan biobased and intelligent films: Monitoring $\mathrm{pH}$ variations. LWT - Food Sci Technol., 55:83-89. 